\title{
MALAYSIA HOUSEHOLD WEALTH DISTRIBUTION: CURRENT EVIDENCE AND FUTURE PROSPECTS
}

\author{
MUHAMMED ABDUL KHALID \\ Institute of Malaysian and International Studies \\ Universiti Kebangsaan Malaysia
}

\begin{abstract}
The paper studies the distribution and inequality of wealth among the household per capita in Malaysia, using the 2007 Malaysia's Household Income Survey (HIS) data. Consistent with findings from other countries, the distribution of wealth is more skewed than that of income. The distribution of wealth shows that the top 10\% of Malaysian households per capita control $35 \%$ of the country's wealth, while the bottom $40 \%$ own $8 \%$. The decomposition of wealth shows that the Gini coefficient for savings is 0.98, while the figure for investment assets and real estate assets are 0.90 and 0.52 respectively. It is expected that wealth inequality will widen in the future due to several factors such as liberalization of the higher education policy and pro-rich tax treatment.
\end{abstract}

Keywords: Inequality, Malaysia, wealth.

\section{Introduction}

Much has been written on the distribution of income and income inequality in Malaysia (see e.g. Ragayah, 2009; Jomo, 2004; Ragayah, 2004; Ragayah, 1999; Shireen, 1998; Ishak \& Ragayah, 1990; Jomo \& Ishak, 1986; Ragayah, 1978; and Ishak \& Ragayah, 1978), but little has been done on the distribution of wealth, perhaps due to the unavailability of data. This is quite surprising considering that Malaysia has among the highest level of income inequality in the region, comparable to those countries in Latin America and Africa. In 2003, the income share received by the highest income decile (measured by Gini) was 39.2, a high concentration compared to just 22.5 for Singapore, 28.5 for Indonesia and 32.4 for Thailand (Leete, 2007). Although there is no data on household net worth in Malaysia, 
there is reason to expect more extreme concentration of wealth in Malaysia compared to income. In all countries where household net worth data is available, the Gini coefficient for household wealth is always more than the Gini coefficient for household income (OECD, 2008; Davies, Sandstrom, Shorrocks, \& Wolff, 2006). The income disparity is not reflective of the net worth or economic well- being of a household or an individual, and to rely solely on the income indicator is misleading and erroneous.

To get a complete picture of the economic well-being of a citizen, it is not sufficient to just look at income or earnings; a study on wealth would be more appropriate. This study will attempt to do just that; the main focus is the disparity gap on household ownership and distribution of wealth, focusing on vertical ${ }^{1}$ inequality rather than horizontal inequality. The analysis will concentrate on the component of wealth i.e. real estate holdings (land and houses) and financial assets (savings and stocks). In most international studies on wealth, the portfolio composition of wealth includes the same components such as home equity, business equity, financial assets, stocks and savings from income, although the concentration of different assets among households varies from one country to another. Our aim is to find out what the differences in wealth among the Malaysian households are.

\section{Data and Methodology}

For this study, data on wealth distribution will be based on processed secondary data, derived from the Household Income Survey (HIS) 2007 obtained from the Economic Planning Unit (EPU). The main objective of the HIS was to collect information on the pattern of income distribution classified by various socioeconomic characteristics in Malaysia. The survey was carried out by the Department of Statistics to collect information on household income and identify poverty groups. For HIS 2007, a total of 38,083 households were covered, which was more than $1 \%$ of the Malaysian population. This study will estimate gross wealth based on the following components: financial assets and real estate holdings. The methodology for deriving at the financial assets and the real estate is as follows: the financial asset is derived from the extrapolation of the sum of income from interest (e.g. bank deposits, bills, bonds, loans, etc) and dividends (e.g. from ownership of shares, unit trusts, etc). ${ }^{2}$ The extrapolation of interest will give us 
'total savings', and dividends will give us 'total investments'. Different yields are assigned to both interest and dividends respectively to get the value of the total savings and total investments. The yield assigned to savings is $2.5 \%$, which is the average of 12 months fixed deposit at a rate of $3.71 \%$ and conventional bank savings rate of $1.30 \%$ in the year 2007. The yield assigned to investments is $5.8 \%$, which is based on the returns from the Employee Provident Fund (EPF) in the year 2007. The real estate asset refers to ownership of residential property. This is derived from the imputed rent of owner occupied house and rent from houses or other property - including both land and house. ${ }^{3}$ In order to get the value of the real estate, a gross rental yield is assigned to the sum of rent of owner-occupied houses and rent from houses or other property, and the property value is then calculated as the annual rental value divided by the rental yield. The assigned yields are as follows: $4 \%$ for urban areas and 3\% for rural areas for all the states, except for Kuala Lumpur where the assigned yield is $5 \%{ }^{4}$ The official exact figures for the yield based on property location and types are not available. As such, the yields are derived from alternate sources.

The analysis is based on the household per capita basis. The inequality analysis will be done using the Gini coefficient index, the Theil index, as well as quantile ${ }^{5}$ and decile percentages measurements.

\section{Results}

\section{Distribution}

The analysis from the Household Income Survey 2007 showed that about $15 \%$ of Malaysian households had no wealth. Although the figure of Malaysians without wealth seems high, the percentage was much lower when compared to the situation in the United States in 1995 where the percentage of Americans with zero wealth then was $18.5 \%$ (Wolff 1998, p. 2). However, the Americans have more financial assets than Malaysians, as their figure for zero financial assets stood at $28.7 \%$ while in Malaysia it was 38\%. The figure was higher in Korea in 1998 , where $40 \%$ of its households had no savings or financial assets (Leipziger et al., 1992, p. 40). Closer to Malaysia, it was reported that the half of the rural and urban households in Indonesia had zero financial wealth in 1997 (Frankenberg et al., 2003, p. 306, in Davies \& Shorrocks, 2005, p. 17). 
The average wealth holding of a Malaysian in 2007 was RM86,6596, while the median was RM71,534. The overall distribution of the wealth holdings is shown in Figure 1 below. The top 10\% households controlled $35.22 \%$ of the wealth distribution, while the bottom $10 \%$ controlled nothing. The bottom $40 \%$, meanwhile, had just $0.15 \%$ of the top $20 \%$; their overall ownership of the wealth holdings equalled to just $8.02 \%$. The average wealth of the bottom $40 \%$ stood at RM39,334, while the figure for the top $20 \%$ was RM124,737, translating into a disparity of 0.31 .

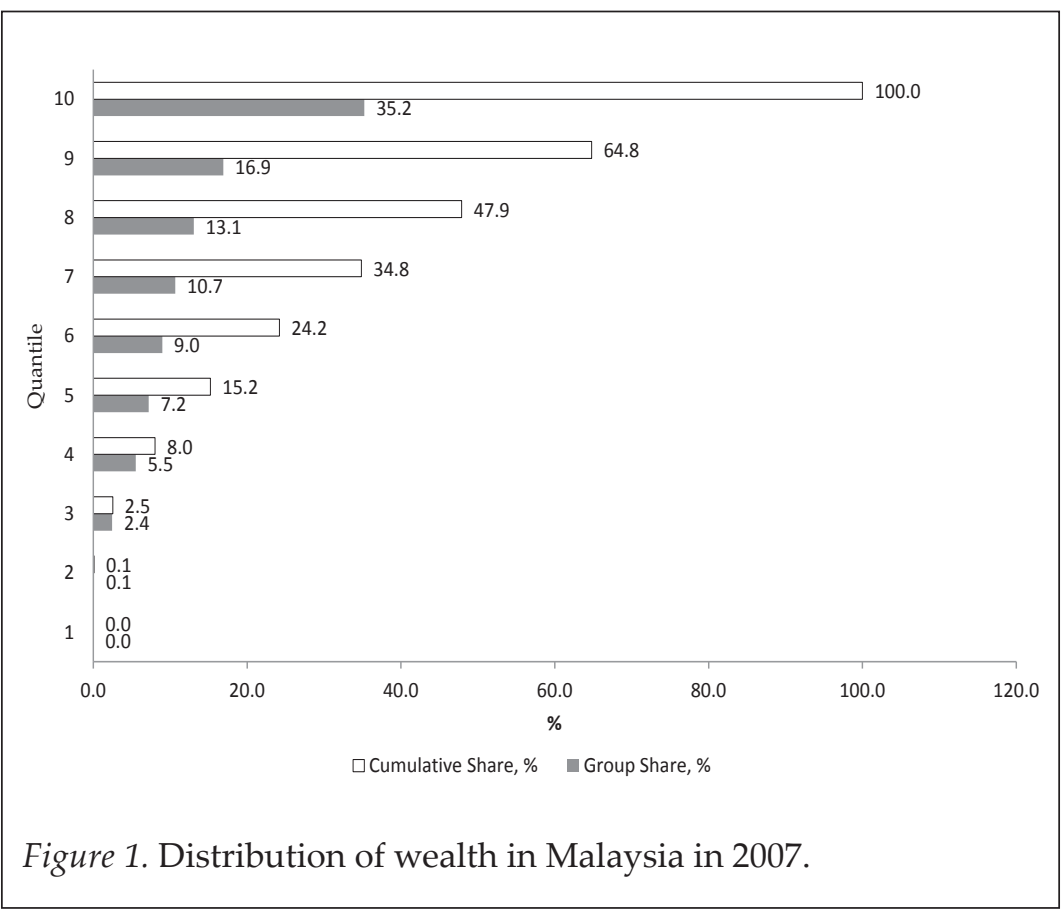

The decomposition of wealth showed that the bulk of the wealth, or about $96 \%$, comprised of real estate assets, while the financial assets contribution to the wealth holdings was quite negligible at about $4 \%$ (Graph 1). This is consistent with the composition of wealth in other countries, where the majority of the wealth consisted of real estate or tangible assets, rather than liquid monetary assets. In Canada, half of the wealth was held in terms of real estate (Matteo, 1997), in the United States the figure was 44\% (Wolff, 1998), in China it was 67\% (Gustafsson et al., 2001) and in Korea and Indonesia, the figure was $90 \%$ and $70 \%$ respectively (Leipziger, Dollar, Shorrocks \& Song, 1992). 


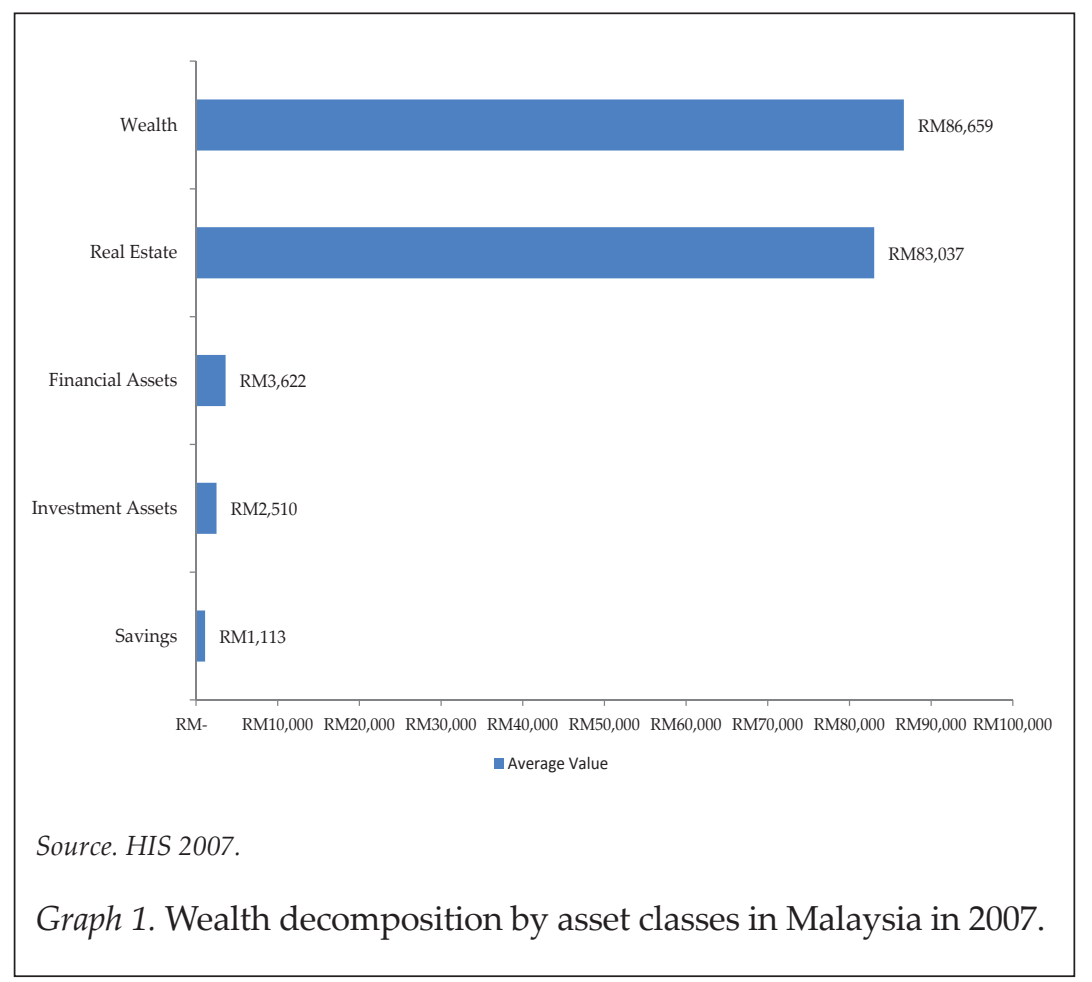

Wealth was better distributed compared to real estate assets or financial assets, at least for the bottom $40 \%$, but not when compared to the income distribution (Table 1). The financial asset holdings distribution was the worst, followed by wealth, property assets, and income. The bottom $40 \%$ had a cumulative share of $14.5 \%$ in income, and slightly more than half of that amount in wealth, and zero in financial assets. The top $20 \%$ controlled nearly all of the financial assets (95\%), while the corresponding figures for wealth, property assets and income were about half of the total holdings. What this means is that the majority of Malaysians had very limited financial resources in relation to their normal consumption and expenditures. The economic insecurity is alarming as the average of the Malaysian household wealth sufficient to sustain current expenditure in case of income loss is 3.2 years, while for those at the bottom $40 \%$ it is 2.6 years, and the bottom $10 \%$ could not survive even one month. Unlike most calculations that use financial wealth as measurement, we used overall wealth because families could sell their houses if their income fell to zero. However, if we measure using liquid assets, the average 
savings of a Malaysian household is enough to cover just 1.8 months of monthly expenditure, while their financial assets could cover about 6 months of monthly expenditure.

Table 1

Distribution of wealth in Malaysia in 2007

\begin{tabular}{lrrrr}
\hline $\begin{array}{c}\text { Distribution of household } \\
\text { per capita }\end{array}$ & Wealth & $\begin{array}{c}\text { Financial } \\
\text { assets }\end{array}$ & $\begin{array}{c}\text { Property } \\
\text { assets }\end{array}$ & Income \\
\hline Top 20 & $52.1 \%$ & $94.9 \%$ & $50.9 \%$ & $49.8 \%$ \\
Middle 40 & $39.9 \%$ & $5.1 \%$ & $41.7 \%$ & $35.7 \%$ \\
Bottom 40 & $8.0 \%$ & $0 \%$ & $7.5 \%$ & $14.5 \%$ \\
\hline
\end{tabular}

Source. HIS 2007.

The skewed distribution of wealth in Malaysia in 2007 was not as extreme as compared to several developed countries a decade or two ago (Table 2). For instance, the top $20 \%$ of the households in the United States had $84 \%$ of the wealth, while the figures for Korea and Sweden were $60 \%$ and $80 \%$ respectively. In fact, the share of wealth of the top $20 \%$ of Malaysia was much lower than in other countries. The distribution of wealth at the bottom $40 \%$ in Malaysia was better than in the United States as in the latter, the bottom $40 \%$ had just $0.2 \%$ of wealth, and $0 \%$ of financial assets (Wolff, 1998, p. 6). Using household balance sheet and survey data, Davies, Sandstrom, Shorrocks and Wolff, (2006) estimated the level and distribution of global household wealth and found that the top $10 \%$ of the world households control $71 \%$ of wealth, with a net worth averaging USD 44,024 (in per capita purchasing power).

Table 2

International Comparison on the Distribution of Wealth for Top 20\%

\begin{tabular}{lcc}
\hline Country & Year & Top 20\% \\
\hline Korea & 1998 & 60 \\
Australia & 1966 & 54 \\
France & 1975 & 69 \\
Canada & 1970 & 74 \\
Sweden & 1975 & 80 \\
United States & 1995 & 85 \\
Malaysia & 2007 & 52 \\
\hline
\end{tabular}

Source. Davies, 1979; Harrison, 1979; Kessler and Masson, 1987; Shorrocks, 1987; and Spant, 1987; in Leipziger, et al., 1992, p. 59.

Figure 2 for Malaysia is from HIS 2007. 


\section{Inequality}

Consistent with other findings that show inequality for wealth is higher than income, the Gini coefficient for wealth in Malaysia in 2007 was 0.5182 , higher than the Gini for income which stood at 0.441 . In terms of assets, the Gini for financial asset was the highest at 0.90, followed by real estate at 0.521 . However, the wealth Gini coefficient for Malaysia was lower compared to the Gini coefficient of global household wealth, and much lower compared to other developed countries in the last one or two decades (Table 3). In fact, the figure for Malaysia was the lowest compared to the rest of the countries listed in Table 3. Malaysia's distribution of wealth and its inequality is not an outlier or extreme to that of other countries.

Table 3

International Comparison on Gini Coefficient in Wealth

\begin{tabular}{llc}
\hline Country & Year & Gini-coefficient \\
\hline World & 2008 & 0.8 \\
USA & 1998 & 0.76 \\
France & 1986 & 0.71 \\
Germany & 1998 & 0.69 \\
Canada & 1984 & 0.69 \\
Italy & 1987 & 0.6 \\
Sweden & 1985 & 0.59 \\
Korea & 1988 & 0.58 \\
Japan & 1984 & 0.52 \\
Malaysia & 2007 & 0.52 \\
\hline
\end{tabular}

Source. Davies \& Shorrocks, 2000; Table 1, and Davies et al., 2008; Shapiro and Wolff, 2001, p.17.

\section{Future Prospects}

The new economic model -NEM- has set the objectives for Malaysia to be a high-income country by 2020 , with an average income per capita of USD 15,000. Nevertheless, the NEM document seems ambiguous, as it sometimes emphasizes market-oriented approaches, and sometimes underplays the need for state intervention to nurture specific industries. A more definite two-pronged state/private sector strategy would therefore be essential. The market-oriented 
policies advocated in NEM will likely increase inequality, as it lacks equalizing policies (e.g. minimum wage, cash transfers, employment creation etc). The emphasis on opportunities, and not outcomes, as stated in the NEM document, would perpetuate inequality, which will directly make the NEM exercise a contradiction to its own stated objectives. It is important to look at outcomes to allow for hidden and past inequalities in opportunities. In addition, the NEM seems less inclined to set targets for its objective, perhaps in consideration of the problems of target-settings, but such targeting can help in monitoring and policy reforms, like the United Nations' Millennium Development Goals (MDGs). It is helpful to consider the national target for poverty, inequalities and the bottom $40 \%$.

Apart from the NEM, several other factors would widen the wealth gap, namely the tax structure, the jump of asset prices, and changes in education policy. The tax structure in Malaysia favours the rich more than the poor, and is contributing to the widening wealth gap. In property assets, previously, the real property gains tax is progressive from zero to $30 \%$, depending on the holding period of the property, but this tax was put on hold from 1 April 2007. Effective 1 Jan 2010, the real property gains tax is $5 \%$ irrespective of the property disposal year. In addition, an exemption to the real property gains tax is given to the sale of a residential property for the first time and transfer of properties among family members. As inheritance play a major role in perpetuating inequality and asset accumulation, the exemption on the transfer of properties inter-generational, regardless of the property value, would increase the gap of inequality between the rich and the poor. In addition, monies received as death gratuity is also $100 \%$ fully exempted from income tax. Basically, the current tax structure would mean that an average salary earner who has an income of RM100,000 will have a marginal maximum tax rate at $26 \%$ (at the same rate as those who earned RM1 million or RM 10 million), the rich person who has a property gain of RM100,000 is taxed at 5\%, while the capital gain tax from financial investment interest of the same amount will not be taxed at all. The structure and evolution of taxation in Malaysia is therefore threatening the distribution of wealth, where the trend appears to be helping in widening the disparity between the rich and the poor. The poor or middle class Malaysians, who have limited sources of income from financial assets or real estate assets have to pay higher tax compared to the rich, whose income mostly come from non-labour sources. The poor and the middle class seem to be taxed much more heavily than the rich, as their interest income and dividend are not taxed. 
The sharp rise in housing prices, as well as other assets, over the last few years in Malaysia can only exacerbate the wide gap between the rich and the poor. We have shown that real estate contributed the most in the wealth composition compared to other asset classes, and thus the ownership of real estate, especially a house, played a major role in wealth holdings. The property value in Malaysia has been increasing beyond the affordability of the average Malaysian wage earners. An average terraced house that sold for RM75,000 in 1988 is now valued around RM191,000 - an increase of 155\% over two decades (Ministry of Finance, 2009). The prices are much higher in main towns and urban areas such as in Kuala Lumpur, Johor Baharu and Georgetown, Penang. In comparison, the latest figure shows that the wage trends in Malaysia indicated a mere $2.6 \%$ growth annually for the past 10 years, while inflation grew at much higher rate during the same period. The housing price is becoming more and more beyond the means of average Malaysians, especially for those living in the urban areas. A study prepared by the Urban Development Authority found that even the cheapest Malaysian public low-cost housing unit is beyond the means of at least $80 \%$ of the lower income group of the urban population (Lim, 2001). The high property prices and increasing cost of living, compounded with lower income growth rate would impede the ability of the poor, especially the urbanites, to purchase and own houses or property asset.

Another factor that will widen the wealth distribution is the changes in education policy, namely in the liberalization of higher education. According to a report by the Ministry of Higher Education, as published in the $10^{\text {th }}$ Malaysian Plan (2010), some 50\% of public funds for higher education will be disbursed based on the needs of the government by 2015, and $25 \%$ of all public university places will be fee-paying seats. Currently, the government subsidizes all seats in public institutions of higher learning at the rate of $90 \%$. Students only have to pay a relatively smaller fee for critical courses compared to those in private institutions. This is made possible because the government subsidized nearly RM8.5 billion a year in order to maintain these low tuition fees. However, it is predicted that by 2020 as many as $90 \%$ of higher education students will have to go through a private institution to obtain their degrees. The implications of the changes in the education policy will affect the poor the most. As about $60 \%$ of Malaysians have zero financial assets, the financial constraints are making it harder for these parents to finance the education of their children. In addition, the meritocracy system is penalizing the rural and poor students as they lack better schools, infrastructure and teachers while the urban students have the better facilities and 
infrastructures. The poor students who are discriminated in the admission process have limited opportunity in gaining admission compared to the relatively well-equipped rich urban students. Unlike the rich students who could afford to enrol in private institutions, the poor have nowhere to go as the higher cost of tertiary education in private colleges or universities is a serious obstacle. The result will be the share of the poor acquiring higher education will probably decrease relative to the rich. The trend will be getting worse, as the $10^{\text {th }}$ Malaysian Plan indicated that the Malaysian government does not plan to build anymore public universities, while the private sector will not be prevented from expanding or setting up private higher education institutions.

\section{Conclusion}

Many approaches are potentially viable when considering ways to improve asset or wealth accumulations, especially for households that have constraints in starting to generate wealth. These may range from regional development strategies to reduce the effects of race and class segregation, job trainings to increase income from earnings, boosting employment, and incentives to assist families in building wealth through asset accumulation. In Malaysia, several policies could be implemented in order to reduce the disparity gap between ethnicity and between income classes. Several ideas have been proposed. Ragayah (2009) proposed more focus on education, mainly in assistance and conducive eco-system for students from the rural areas, increase the income of the poor and of the bottom households, re-stressing on rural developments, more involvement from the government, restructure taxation, and caring society. The Malaysia National Economic Advisory Council (NEAC), in their New Economic Model (NEM) report issued in 2010, suggested that the government should widen the social safety net and restructure the affirmative action from ethnic-based to need-based for the bottom $40 \%$ of households (National Economic Advisory Council, 2010). CMI (2005) suggested, among others, reform in basic schooling, introducing child grant, upgrading productivity in agriculture sector, and anti-discrimination policies in order to reduce the economic disparity. Other proposals included the need to promote asset acquisitions among those at the bottom of the social structure who have been locked out of the wealth accumulation process. The focus is on facilitating savings and the accumulation of assets for low income families and the poor who usually fall outside of traditional 
asset building opportunities. Additionally, the massive concentration of wealth that is held by the richest Malaysians must be addressed. Without redistributing the wealth, the creation of just and harmonious society will never be achieved.

Inaction in addressing the wealth gap is a recipe for disaster. Correct and immediate policy changes are required to address this unjust imbalance, as not only that it is unfair and detrimental to economic growth and well-being, but also will create divisions and strain relations amongst the people, and could tear the country apart. Unless bold and drastic actions are taken soon, a harmonious future for Malaysia is uncertain. There must be an urgency to give every Malaysian economic security, for better and sustainable futures that are essential for a stable, harmonious and a prosperous society.

\section{End Notes}

1. Horizontal inequality is the inequality between groups - such as citizenship, race, ethnicity, religion, gender, region, and others. Vertical inequality refers to inequality between individuals or households with respect to income, consumption and asset. Vertical inequality can be decomposed into two elements: between group inequality and within group inequality.

2. In HIS, the interest and dividend income is coded as INCS 33 and INCS 34 respectively.

3. The code from HIS 2007 from imputed rent from owneroccupied house and rent from other houses and property are incs 22 and incs 23 respectively. Incs 23 includes both land and house, but since we cannot isolate them, the sum of incs22 and incs 23 is referred to as real estate. Otherwise, it could be labelled as house and land separately.

4. The figures for the yields are from author conversations and email correspondences with several Malaysian property developers and reputable real estate agents. The exact yields are not available from official reports.

5. Quantiles are a set of 'cut points' that divide a sample of data into groups containing equal numbers of observations. Examples of quantiles include quintile (five groups), quartile (four groups) and percentile (one hundred groups).

6. $\mathrm{RM} 1=0.25 €$ 


\section{References}

Abraham, C. (1997). Divide and rule: The roots of race relations in Malaysia. Kuala Lumpur: INSAN.

Alatas, S. H. (1972). Siapa yang salah: Sekitar revolusi mental dan peribadi Melayu (Who is at fault: Mental revolution and Malay psyche). Singapore: Pustaka Nasional Singapura.

Alatas, S. H. (1977). The myth of the lazy native. London: Frank Cass.

Anand, S. (1983). Inequality and poverty in Malaysia: Measurement and decomposition. Washington: Oxford University Press.

Atkinson, A. B., \& Burguignon, F. (2000). Income distribution and economics. In Atkinson, \& Bourguinon (Eds.), Handbook of income distribution Volume 1. Amsterdam: North Holland.

Benabou, R. (1996). Unequal Societies. NBER Working Paper, 5583.

Chua, A. (2003). World on fire: How exporting free-market deocracy breeds ethnic hatred and global instability. London: William Heinemann.

CMI. (2005). Growth with distribution: Strategies for improved income distribution in Malaysia. Bergen: Chr. Michelsen Institute.

Davies, J. B., \& Shorrocks, A. (2000). The distribution of wealth. In Atkinson \& Bourguignon (Eds.), Handbook of income distribution, Volume 1. Amsterdam: North Holland.

Davies, J. B., Sandstrom, S., Shorrocks, A., \& Wolff, E. N. (2009). The level and distribution of global household wealth. NBER Working Paper Series, Working Paper 15508.

Davies, J. B., Sandstrom, S., Shorrocks, A., \& Wolff, E. N. (2006, Dec). The world distribution of household wealth. WIDER Discussion Paper, 3.

Davies, J. B., \& Shorrocks, A. (2005). Wealth holdings in developing and transition countries. Paper presented at the Luxembourg Wealth Study (LWS) conference on "Construction and Usage of Comparable Microdata on Wealth" in Perugia 27-29 January 2005. Italy.

EPU. (2008). Malaysian economy in figures 2008. Retrieved from http:// www.epu.gov.my

Faaland, J., Parkinson, J., \& Saniman, R. (2003). Growth and ethnic inequality. Kuala Lumpur: Utusan Publications \& Distributors.

Firdaus, Abdullah. (1997). Affirmative action policy in Malaysia: To restructure society, to eradicate poverty. Ethnic Studies Report, XV.

Gomez, E. T., \& Ghee, L. T. (2006). Corporate equity distribution: Past trends and future policy. Asian Strategy and Leadership Institute. Kuala Lumpur: Center for Public Policy Studies , ASLI.

Gustafsson, B., \& Johansson, M. (1999). In search of smoking guns: What makes income inequality vary over time in different countries? American Sociological Review, 64(4), 585-605. 
Gustafsson, B., Shi, L., \& Zhong, W. (2001). Household wealth in urban China in 1995: Composition, inequality and determinants. Journal of Economic Literature,

Gylfason, T., \& Zoega, G. (2003). Inequality and economic growth: Do natural resources matter? In T. S. Eicher, \& S. J. Turnvosky, Inequality and growth: Theory and policy implications. CESifo Seminar Series. MIT Press.

Hashim, W. (1983). Race relations in Malaysia. Kuala Lumpur: Heinemann Educational Books Asia.

Hirschman, C. (1989). Development and inequality in Malaysia: From Puthuchaery to Mehmet. Pacific Affairs, 62(1), 72-81.

Ishak, S., \& Zin, R. H. (1990). Agihan pendapatan dalam kalangan orang Melayu di Semenanjung Malaysia - Satu penilaian (An analysis of income distribution among the Malays in Peninsula Malaysia). Kuala Lumpur: Faculty of Economics, Universiti Kebangsaan Malaysia.

Ishak, S., \& Zin, R. H. (1990). The patterns and trends of income distribution in Malaysia 1970-1987. Singapore Economic Review, XXXV (1).

Jomo, K. (1986). A question of class: Capital, the state, and uneven development in Malaya. Singapore: Oxford University Press.

Jomo, K. (2004). The new economic policy and interethnic relations in Malaysia. New York: United Nations Reseach Institute for Social Development.

Leete, R. (2007). Malaysia: From kampung to twin towers. Kuala Lumpur: Fajar Oxford.

Leipziger, D., Dollar, D., Shorrocks, A., \& Song, S. (1992). The distribution of income and wealth in Korea. Washington DC: World Bank.

Lim Jee Yuan (2001). The traditional Malay house. Retrieved from http:// idl-bnc.idrc.ca/

Malaysia. (2010). 10th Malaysian Plan. Government of Malaysia.

Malaysia. (1971). 2nd Malaysian Plan. Government of Malaysia.

Matteo, L. D. (1997). The determinants of wealth and asset holdings in nineteeth-century Canada: Evidence from Microdata. The Journal of Economic History, 57(2), 907-934.

Milanovic, B. (2007). Global income inequality: What it is and why it matters. In Jomo, K. S., \& J. Baudot (Eds.), Flat world, big gaps: Economic liberalization, globalization, poverty and inequality. New York: United Nations Publications.

National Economic Advisory Council. (2010). The new economic model for Malaysia. Kuala Lumpur: Percetakan Nasional Malaysia Berhad.

OECD. (2008). Growing unequal: Income distribution and poverty in OECD countries. OECD, Paris.

Puthucheary, J. (1960). Ownership and control in the Malayan economy. Singapore: Eastern Universities. 
Ragayah, H. M. (2008). Explaining the trend in Malaysian income distribution. Kuala Lumpur: Universiti Kebangsaan Malaysia Press. Institute of Malaysian and International Studies.

Ragayah, H. M. (2009). Growth and inequality: Reality and aspiration. Bangi: Universiti Kebangsaan Malaysia Press.

Ragayah, H. M. (1999). Growth with equity: Policy lessons from the experience of Malaysia. In Growth with equity: Policy lessons from the experiences of selected Asian countries (pp. 117-62). New York: United Nations.

Ragayah, H. M. (2009). Poverty reduction, social integration $\mathcal{E}$ development: The formula for peace. Bangi: Universiti Kebangsaan Malaysia Press.

Ragayah, H. M. (1978). Some aspects of income inequality in Peninsular Malaysia, 1957-1970. Council of Asian Manpower Studies (CAMS) Discussion Paper Series No. 78-01.

Ragayah, H. M., \& Shari, I. (1978). Some aspects of income inequality in Peninsular Malaysia, 1957-1970. In H. O. Mizoguchi, Income distribution by sectors and over time in east and southeast Asian countries (pp. 228-258). Quezon City, Philippines and IADRPHU, Institute of Economic Research, Hitotsubashi University, Tokyo: Selected Papers Presented for the CAMS-Hitotsubashi Seminar.

Schafgans, M. M. (1998). Ethnic wage differences in Malaysia: Parametric and semiparametric estimation of the ChineseMalay wage gap. Journal of Applied Econometrics, 13(5), 481-504. Shireen, M. H. (1998). Income inequalities and poverty in Malaysia. Kuala Lumpur: Lanham, Md Rowand \& Littlefield Publishers.

Stiglitz, J. (1969). Distribution of income and wealth among individuals. Econometrical, 37, 382-97.

Wolff, E. N. (1987). International comparison of the distribution of household wealth. Oxford: Oxford University Press.

Wolff, E. N. (1992). Changing inequality of wealth. The American Economic Review, 82(2), 552-558.

Wolff, E. N. (1998). Recent trends in the size distribution of household wealth. The Journal of Economic Perspectives, 12(3), 131-150.

Wolff, E. N. (2002). Inheritances and wealth. The American Economic Review, 92(2), 260-264.

Woodward, D., \& Simms, A. (2007). Growth is failing the poor: The unbalanced distribution of the benefits and costs of global economic growth. In Jomo, \& Baudot (Eds.), Flat world, big gaps: economic liberalization, globalization, poverty and inequality. New York: United Nations Publications. 